\title{
Appropriate Epitope Retrieval for c-kit Protein Immunostaining in Routinely Prepared Specimens of Gastrointestinal Stromal Tumor
}

\author{
Atsuji Matsuyama ${ }^{1}$, Shingo Kamoshida ${ }^{1}$, Yoshikazu Mizoguchi', Ryoichi Shimomura', \\ Yutaka Hirasawa ${ }^{2}$, Ken-ichi Inada ${ }^{1}$ and Yutaka Tsutsumi ${ }^{1}$ \\ ${ }^{1}$ Department of Pathology, Fujita Health University School of Medicine and ${ }^{2} J o i n t$ Research Clinical Laboratory, Fujita \\ Health University Hospital, Toyoake, Aichi 470-1192, Japan
}

Received September 18, 2003; accepted December 2, 2003

Gastrointestinal stromal tumor (GIST), immunohistochemically characterized by c-kit protein (CD117) expression, is known to be resistant to chemotherapy and radiotherapy when it is malignant. Recently, Gleevec (STI571) has been introduced for the therapy of metastatic GISTs, and appropriate evaluation of ckit protein has thus been clinically relevant to confirm the indication of Gleevec therapy. However, we often experienced the instability of immunohistochemical staining for c-kit protein. The aim of the present study is to establish a reproducible immunohistochemical procedure for c-kit protein detection in paraffin sections. Regarding the fixation period, for- malin fixation for $\mathbf{2 4}$ to $\mathbf{7 2}$ hours gave the best result among several fixation conditions. For the purpose of epitope retrieval, hydrated heating in EDTA solution, pH 8.0, employing a pressure cooker gave the most reproducible immunostaining result. For visualization of the reaction products, diaminobenzidine solution available from DakoCytomation Co. was the most sensitive. Under these conditions, c-kit protein immunoreactivity was clearly observed in $20(95 \%)$ of 21 GISTs, routinely processed for histologic preparation. Two tumors were proven to be false negative by the routine diagnostic procedure.

Key words: gastrointestinal stromal tumor, c-kit protein, immunohistochemistry, antigen retrieval, EDTA

\section{Introduction}

Gastrointestinal stromal tumor (GIST) is one of the most frequent mesenchymal neoplasms of the gastrointestinal tract [10]. GISTs are thought to arise from interstitial cells of Cajal, which are characterized by immunohistochemical expression of CD34 and/or c-kit protein (CD117) [8]. The peroral administration of Gleevec (STI571), an antagonist against tyrosine kinase of such oncoproteins as bcr/abl, c-kit and c-sis [9, 12], has begun to be applied to treat and control metastatic GISTs [2, 3, 19]. A reproducible and reliable evaluation of c-kit protein expression in the tumor cells of GISTs is thus needed. However, we often experienced the instability of immunohistochemical staining for c-kit protein, and when "negative", it is essential to judge whether or not the immunohistochemical result is indeed

Correspondence to: Yutaka Tsutsumi, M.D., Department of Pathology, Fujita Health University School of Medicine, Toyoake, Aichi 4701192, Japan. E-mail: tsutsumi@fujita-hu.ac.jp correct.

The aim of this study is to determine a reproducible and thus clinically critical immunohistochemical procedure for c-kit protein detection in routinely prepared paraffin sections.

\section{Materials and Methods}

In the present study, GISTs were defined in this study as primary spindled or epithelioid mesenchymal tumors of the gastrointestinal tract, omentum, or mesentery, with immunoexpression of CD34 and/or c-kit protein [8, 13]. Tumors judged as c-kit protein-negative in the diagnostic procedures were included, because the purpose of the present study was to improve the immunohistochemical detection of c-kit protein. We evaluated a total of 21 lesions of GIST routinely prepared for histologic examination. In one case, fresh tumor material was immersed in $10 \%$ unbuffered formalin for $2 \mathrm{hr}, 6 \mathrm{hr}, 24 \mathrm{hr}, 72 \mathrm{hr}$ and 1 week, and in acetone for 1 week. We tried to establish immunohistochemical stain- 
ing conditions, as follows. For epitope retrieval, sections underwent heating treatment in one of three solutions, 10 $\mathrm{mM}$ citrate buffer, $\mathrm{pH} 6.0$ (CB6) or $\mathrm{pH} 7.0$ (CB7), or $1 \mathrm{mM}$ ethylenediamine tetraacetic acid (EDTA) solution, $\mathrm{pH}$ 8.0, and by either of the four different heating techniques, such as waterbathing at $95^{\circ} \mathrm{C}$ for $40 \mathrm{~min}$, microwaving (MWF-2, NISSHIN-EM, Japan) at $100^{\circ} \mathrm{C}$ for $15 \mathrm{~min}$, autoclaving (PS-220, TOMY, Japan) at $121^{\circ} \mathrm{C}$ for $10 \mathrm{~min}$, or pressure cooking (Delicio 6L, T-FAL, Clithy, France) [7] at $120^{\circ} \mathrm{C}$ for $10 \mathrm{~min}$. For the control purpose, specimens without any epitope retrieval procedure were tested. After the epitope retrieval, specimens were incubated with the polyclonal anti-c-kit protein antibody (diluted at 1:50, DakoCytomation, Kyoto, Japan) at room temperature for $1 \mathrm{hr}$. After rinsing in $10 \mathrm{mM}$ phosphate-buffered saline (PBS), $\mathrm{pH} 7.2$, the antigenic sites were linked with one of the three different immunoperoxdase techniques, such as avidin-biotinylated peroxidase complex method (ABC, DakoCytomation), labeled streptavidin biotinylated antibody method (LSAB, Histofine SAB-PO kit, Nichirei, Tokyo, Japan) and universal immunoenzyme amino acid polymer method (Histofine Simple Stain MAX PO, Nichirei). For visualization of the reaction products, one of the three different diaminobenzidine (DAB) solutions was applied, including commercial solutions available from DakoCytomation and Nichirei, or DAB prepared in our laboratory (DAB20). DAB20 was a solution of $20 \mathrm{mg} / \mathrm{dl} \mathrm{DAB}$ containing $0.003 \%$ hydrogen peroxide in $0.05 \mathrm{~mol} / \mathrm{L}$ Tris$\mathrm{HCl}$ buffer, $\mathrm{pH}$ 7.6.

The other 20 lesions were immunostained under two of the most sensitive conditions, i.e., either with the epitope retrieval by heating in EDTA or CB7 using a pressure cooker, or the amino acid polymer method and the visualization in DakoCytomation's DAB solution. The fixation periods of the 21 surgical materials, including one case examined for the fixation and staining conditions, ranged from 1 day to 5 days, with an average of 2.1 days and a median of 2 days. The immunohistochemical findings were compared with those by the routine diagnostic immunohistochemical method, which had been performed in Fujita Health University Hospital. For routine practice, they employed the same primary antibody, the epitope retrieval method by microwaving in CB7, link staining with the ENVISION kit (Dextran polymer method supplied by DakoCytomation), and the visualization in DAB20.

We evaluated the immunoreactivity of the respective specimens by the positive area and intensity.

1) Area: The positive area of the tumor cells (area of the positive tumor cells/entire area of the tumor cells) was evaluated with the following formula. The percentage of the positive area was scored from 0 to 3 : Area $3, \geq 75 \%$ of tumor cells positive. Area $2,50-75 \%$ of tumor cells positive. Area $1,25-50 \%$ of tumor cells positive. Area $0,<25 \%$ of tumor cells positive.

2) Intensity: We also scored each immunohistochemical result based upon the staining intensity: Intensity 3, strong immunoreaction easily recognized macroscopically.
Intensity 2, weaker immunoreaction than intensity 3 but recognizable macroscopically. Intensity 1 , though unclear macroscopically, recognizable microscopically under highpowered magnification. Intensity 0 , equivocal or negative microscopically.

As an internal control, c-kit protein immunoreactivity of mast cells [11] was evaluated. We also performed immunostaining using a monoclonal antibody to mast cell tryptase antibody (diluted at 1:50, clone: AA1, DakoCytomation). Antigenicity of mast cell tryptase was retrieved by $0.2 \%$ trypsin at $37^{\circ} \mathrm{C}$ for $15 \mathrm{~min}$, and the amino acid polymer method was utilized. The number of c-kit proteinpositive mast cells was compared with that of mast cell tryptase-immunoreactive cells.

\section{Results}

Effects of fixation on the immunohistochemical demonstration of c-kit protein in one representative GIST specimen are summarized in Figure 1 and Tables 1-3. Formalin fixation for 24 and $72 \mathrm{hr}$ provided the best staining, while formalin fixation for $2 \mathrm{hr}, 6 \mathrm{hr}$ and 1 week, and acetone fixation for 1 week resulted in weak or negligible staining. In sections antigen-retrieved by pressure cooking in EDTA solution, formalin fixation for $6 \mathrm{hr}$ gave the intensity almost equal to 24 or $72 \mathrm{hr}$ (Fig. 1). Without the epitope retrieval sequence, the tumor cells showed negative immunoreactivity (Fig. 2a). Heating in EDTA or CB7 provided much better immunostaining than heating in CB6 (Table 1, Fig. 2e-g). Among the heating techniques, autoclaving and pressure cooking were much better than waterbathing and microwaving (Table 1, Fig. 2b-i). However, autoclaving, especially in CB7, frequently damaged sections and were accompanied by a peeling-off effect (Fig. $2 \mathrm{~h}-\mathrm{i}$ ). The ABC method and LSAB method were less sensitive than the Simple Stain method (Table 2, Fig. 2f, j-k). Regarding the coloring reagent, the DakoCytomation's DAB solution revealed the strongest staining, and the reagent available from Nichirei gave the weakest reaction (Table 3, Fig. 2f, 1-m).

Under the most suitable staining conditions (the epitope retrieval by pressure cooking in EDTA or CB7, detection by the Simple Stain method, and the coloring reaction in the DakoCytomation's DAB solution), the remaining 20 GISTs were immunostained (Table 4). Immunohistochemical results were compared with those obtained for the routine diagnostic purpose in Fujita Health University Hospital. Generally, the intensity of c-kit protein immunostaining was increased, when compared with sections stained in the routine practice, and pressure cooking in EDTA demonstrated stronger immunostaining than pressure cooking in CB7. Three lesions had been judged c-kit protein-negative in routine preparations, but only one lesion was regarded negative after pressure cooking in EDTA or CB7. The fixation period of this particular lesion was 2 days. Mast cells were immunoreactive for c-kit protein within this c-kit protein-negative lesion, but the number of c-kit proteinimmunoreactive cells was slightly less than that of mast cell 


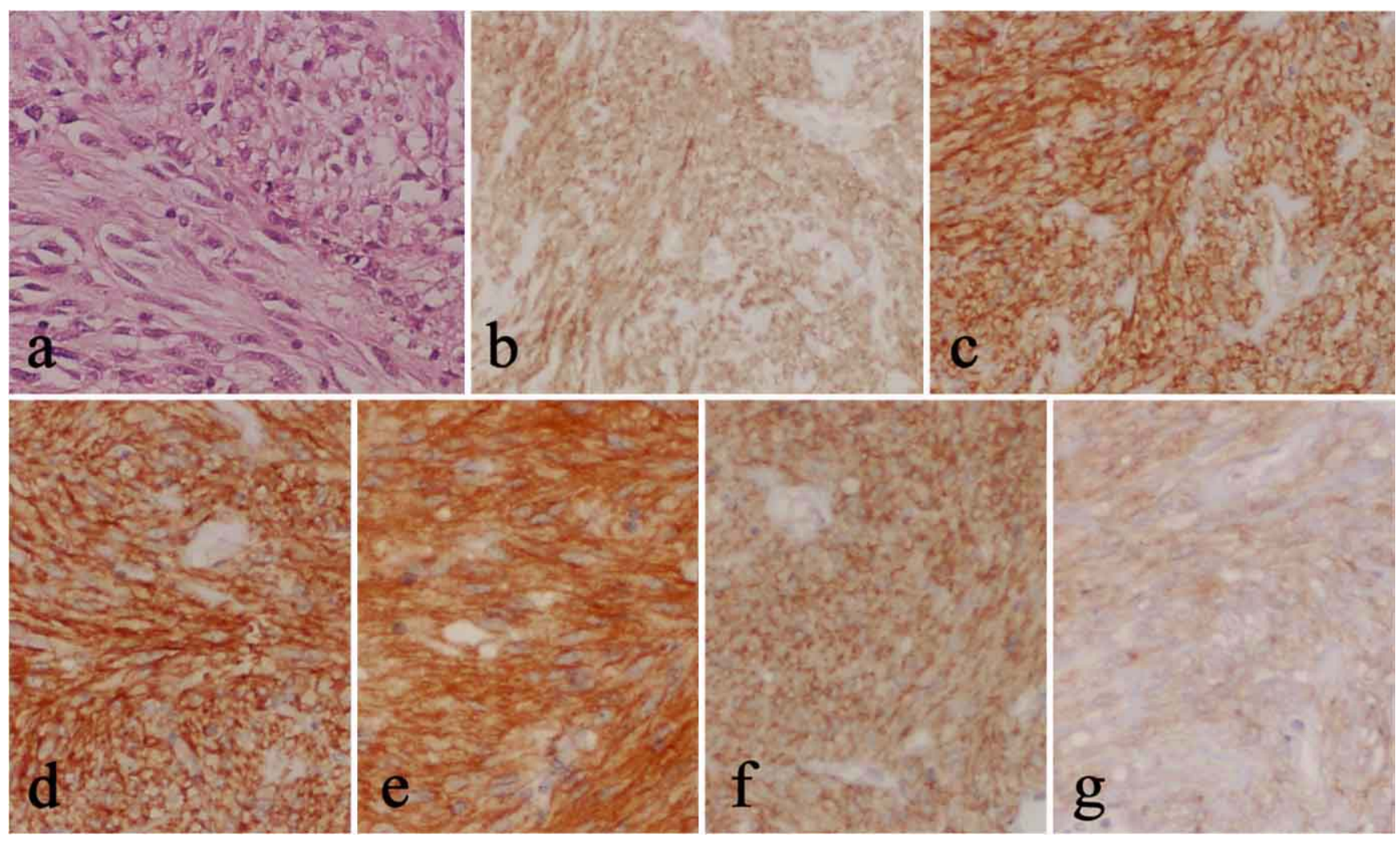

Fig. 1. c-kit protein immunostaining in one GIST under different fixation conditions. a: H-E stain. The specimens fixed in $10 \%$ formalin for 6 hr (c), $24 \mathrm{hr}(\mathbf{d})$ or $72 \mathrm{hr}(\mathbf{e})$ showed the strongest membrane immunoreaction. Formalin fixation for $2 \mathrm{hr}$ (b), 1 week (f) or acetone fixation for 1 week (g) revealed weaker staining. Immunostaining after pressure cooking in $1 \mathrm{mM}$ EDTA solution, $\mathrm{pH}$ 8.0, linked by Simple Stain, and visualized in DakoCytomation's DAB solution.

Table 1. Immunostaining for c-kit protein under different fixation and epitope retrieval conditions (Simple stain method with coloring reaction in DakoCytomation's DAB solution)

\begin{tabular}{|c|c|c|c|c|c|c|c|}
\hline \multirow{2}{*}{ Epitope retrieval } & \multirow[t]{2}{*}{ Fixation } & \multicolumn{5}{|c|}{ Formalin } & \multirow{2}{*}{$\begin{array}{r}\text { Acetone } \\
1 \text { week }\end{array}$} \\
\hline & & $2 \mathrm{hr}$ & $6 \mathrm{hr}$ & $24 \mathrm{hr}$ & $72 \mathrm{hr}$ & 1 week & \\
\hline \multirow{3}{*}{ Waterbathing } & $\mathrm{CB} p H 6.0$ & $0 / 0$ & $0 / 0$ & $0 / 0$ & $1 / 1$ & $0 / 0$ & $0 / 0$ \\
\hline & CB pH 7.0 & $0 / 0$ & $3 / 1$ & $3 / 1$ & $3 / 1$ & $2 / 1$ & $0 / 0$ \\
\hline & EDTA & $2 / 1$ & $3 / 1$ & $3 / 2$ & $3 / 2$ & $3 / 2$ & $2 / 1$ \\
\hline \multirow{3}{*}{ Microwaving } & CB pH 6.0 & $0 / 0$ & $1 / 1$ & $2 / 1$ & $2 / 1$ & $2 / 1$ & $0 / 0$ \\
\hline & $\mathrm{CB}$ pH 7.0 & $1 / 1$ & $1 / 1$ & $2 / 1$ & $2 / 1$ & $2 / 1$ & $1 / 1$ \\
\hline & EDTA & $3 / 1$ & $3 / 2$ & $3 / 3$ & $3 / 3$ & $3 / 2$ & $3 / 2$ \\
\hline \multirow{3}{*}{ Autoclaving } & $\mathrm{CB}$ pH 6.0 & $3 / 1$ & $2 / 2$ & $2 / 2$ & $3 / 2$ & $2 / 2$ & $1 / 1$ \\
\hline & CB pH 7.0 & $1 / 1$ & $3 / 2$ & $3 / 2$ & $3 / 3$ & $3 / 3$ & $2 / 2$ \\
\hline & EDTA & $3 / 2$ & $3 / 2$ & $3 / 3$ & $3 / 3$ & $3 / 2$ & $3 / 2$ \\
\hline \multirow{3}{*}{ Pressure Cooking } & $\mathrm{CB}$ pH 6.0 & $1 / 1$ & $1 / 1$ & $1 / 1$ & $3 / 1$ & $2 / 1$ & $0 / 0$ \\
\hline & CB pH 7.0 & $3 / 1$ & $3 / 2$ & $3 / 3$ & $3 / 3$ & $2 / 3$ & $0 / 0$ \\
\hline & EDTA & $3 / 2$ & $3 / 3$ & $3 / 3$ & $3 / 3$ & $3 / 2$ & $3 / 2$ \\
\hline None & & $0 / 0$ & $0 / 0$ & $0 / 0$ & $0 / 0$ & $0 / 0$ & $0 / 0$ \\
\hline
\end{tabular}

CB: 10 mM citrate buffer. EDTA: 1 mM EDTA solution, $\mathrm{pH}$ 8.0.

Results are scored as "area/intensity".

Area $3, \geq 75 \%$ of tumor cells positive. Area $2,50-75 \%$ of tumor cells positive. Area $1,25-50 \%$ of tumor cells positive. Area $0,<25 \%$ of tumor cells positive.

Intensity 3 , strong immunoreaction easily recognized macroscopically. Intensity 2 , weaker immunoreaction than intensity 3 , though recognized macroscopically. Intensity 1, unclear macroscopically, but recognizable microscopically using high power magnification. Intensity 0 , equivocal or negative microscopically. 


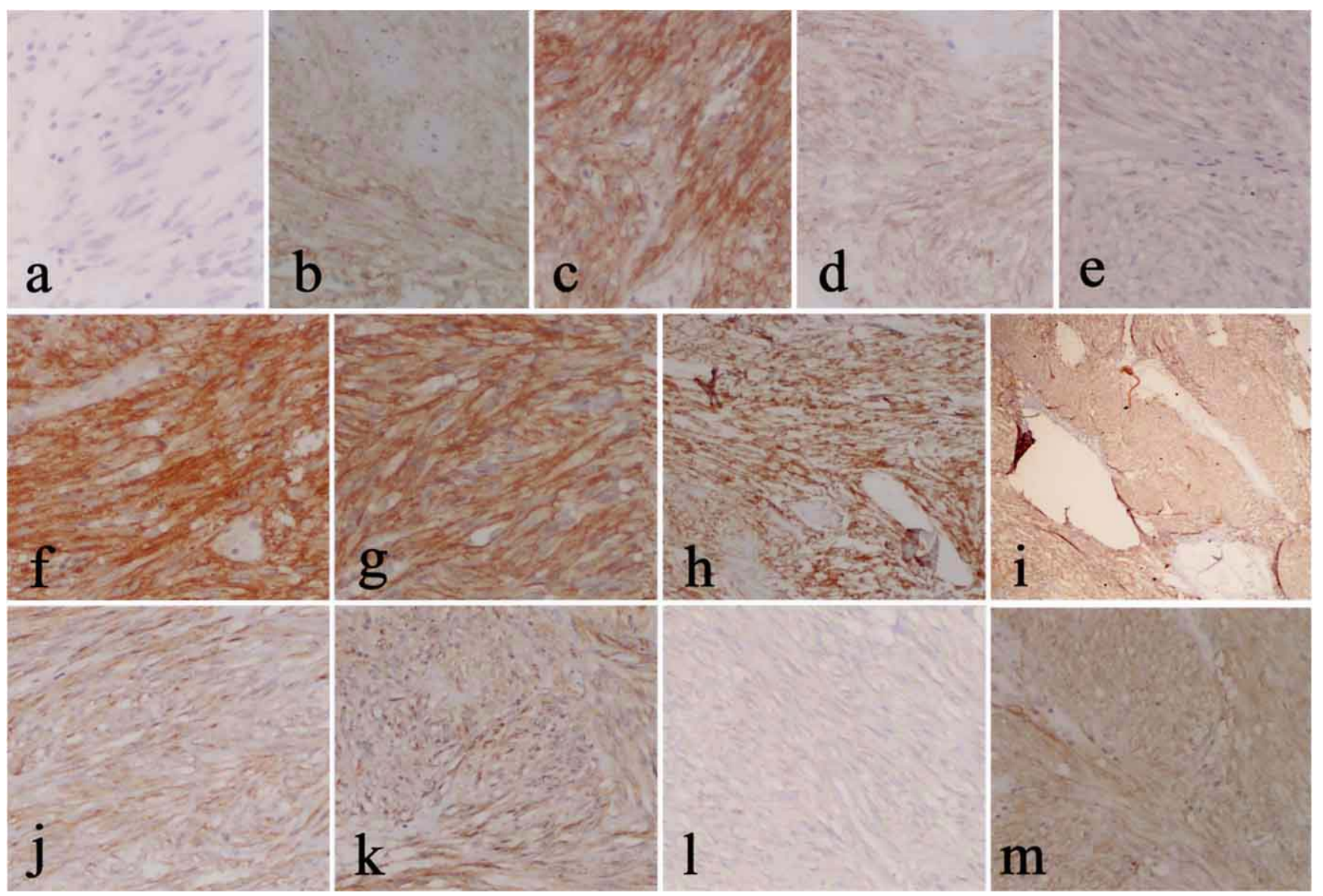

Fig. 2. Immunostaining for c-kit protein in representative specimens of the formalin-fixed, paraffin-embedded GIST. The section without epitope retrieval (a) gave negative finding. Among the different epitope retrieval techniques, pressure cooking (f, g) showed the strongest staining, when compared with waterbathing (b) and microwaving (c, d) (b, c, f: heating in EDTA, d, g: in CB7, Simple Stain, DakoCytomation's DAB). Pressure cooking in CB6 (e) showed weak immunoreactivity (Simple Stain, DakoCytomation's DAB). Autoclaving in EDTA (h) and CB7 (i) provided strong immunostaining, but damage of the section (peel-off effect) was often encountered, especially in CB7. The ABC method (j) and LSAB method (k) gave weaker staining than the Simple Stain method (f) (f, j, k: pressure cooking in EDTA, DakoCytomation's DAB). Immunoreaction by the Nichirei's DAB solution (I) and DAB20 (m) was less intense than that of the DakoCytomation's DAB solution (f) (l, $\mathbf{m}$ : pressure cooking in EDTA, Simple Stain).

Table 2. Immunostaining for c-kit protein with different fixation and detection methods (Pressure cooking in EDTA with coloring reaction in DakoCytomation's DAB solution)

\begin{tabular}{|c|c|c|c|c|c|c|}
\hline \multirow[b]{2}{*}{ Detection Methods } & \multicolumn{5}{|c|}{ Formalin } & \multirow{2}{*}{$\begin{array}{c}\text { Acetone } \\
1 \text { week }\end{array}$} \\
\hline & $2 \mathrm{hr}$ & $6 \mathrm{hr}$ & $24 \mathrm{hr}$ & $72 \mathrm{hr}$ & 1 week & \\
\hline $\mathrm{ABC}$ & $3 / 1$ & $3 / 2$ & $3 / 2$ & $3 / 2$ & $2 / 1$ & $0 / 0$ \\
\hline LSAB & $3 / 1$ & $3 / 2$ & $3 / 2$ & $3 / 2$ & $2 / 1$ & $0 / 0$ \\
\hline Simple stain & $3 / 2$ & $3 / 3$ & $3 / 3$ & $3 / 3$ & $3 / 2$ & $3 / 2$ \\
\hline
\end{tabular}

Results are scored as "area/intensity".

Regarding the scoring method, see legend to Table 1.

tryptase-immunoreactive cells (Fig. 3a-c). It is of additional note that in 9 lesions, the tumor cells were not uniformly immunoreactive for c-kit protein (the intensity varied from area to area) even under the most suitable staining conditions (Fig. 3d). The fixation periods in these 9 lesions were not significantly different from the remaining 12 lesions, and ranged from 1 to 5 days, with an average of 2.0 days and a median of 2 days.

\section{Discussion}

Reports have shown the different immunohistochemi- 

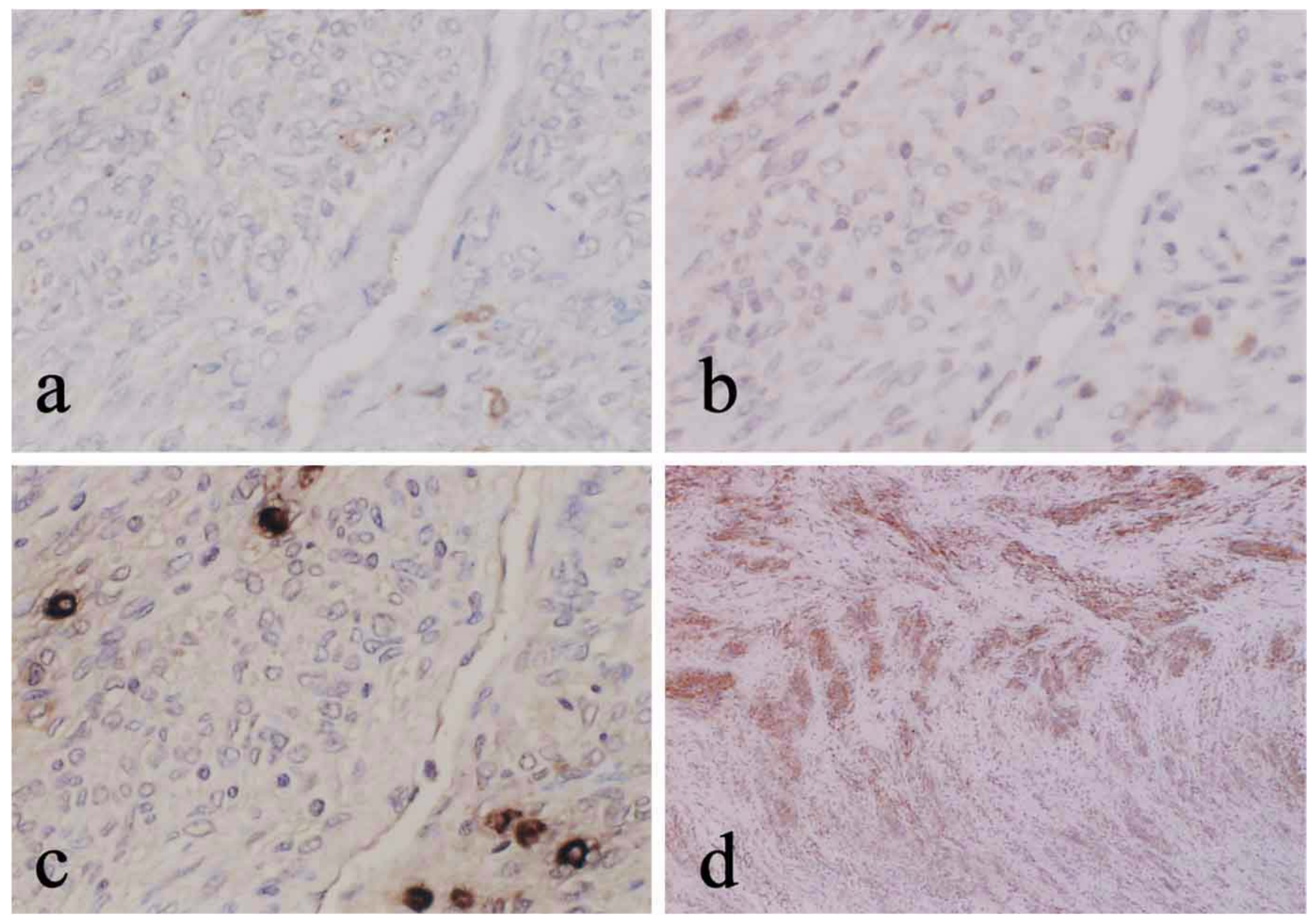

Fig. 3. a-c: Immunostaining for c-kit protein after pressure cooking in EDTA (a) or CB7 (b), and for mast cell tryptase (c) in one c-kit proteinnegative GIST. The number of c-kit protein-positive mast cells seems to be less than that of the mast cell tryptase-positive cells. $\mathbf{d}$ : A mosaic pattern of c-kit protein expression. Such mosaicism was seen in 9 of 21 GISTs examined.

Table 3. Immunostaining for c-kit protein using three different DAB solutions (Simple Stain method with pressure cooking in EDTA)

\begin{tabular}{|c|c|c|c|c|c|c|}
\hline \multirow[b]{2}{*}{ DAB Solution } & \multicolumn{5}{|c|}{ Formalin } & \multirow{2}{*}{$\begin{array}{c}\text { Acetone } \\
1 \text { week }\end{array}$} \\
\hline & $2 \mathrm{hr}$ & $6 \mathrm{hr}$ & $24 \mathrm{hr}$ & $72 \mathrm{hr}$ & 1 week & \\
\hline DakoCytomation's DAB & $3 / 2$ & $3 / 3$ & $3 / 3$ & $3 / 3$ & $3 / 2$ & $3 / 2$ \\
\hline Nichirei's DAB & $0 / 0$ & $0 / 0$ & $3 / 1$ & $3 / 1$ & $0 / 1$ & $0 / 0$ \\
\hline DAB20 & $3 / 1$ & $3 / 1$ & $3 / 2$ & $3 / 2$ & $3 / 1$ & $1 / 1$ \\
\hline
\end{tabular}

Results are scored as "area/intensity".

Regarding the scoring method. See the legend to Table 1.

cal results regarding the c-kit protein expression rate in GISTs, ranging from $72 \%$ to $100 \%$ of $[13,15,16,18,20]$. It is supposed that the immunohistochemical procedure influences the c-kit positivity rate. Our findings indicated that for the reproducible immunohistochemistry of c-kit protein, the specimens should be fixed in formalin for 1-5 days, the sections should be pressure-cooked in $1 \mathrm{mM}$ EDTA solution, $\mathrm{pH}$ 8.0, and the antigen should be visualized by the amino acid polymer technique and DakoCytomation's DAB solution. The critical epitope retrieval procedure may increase the intensity of immunostaining even under the excessive or poor fixation condition. In fact, false negative results were experienced in two of the 21 GISTs during our routine diagnostic procedure. One tumor remained negative even after the most appropriate immunohistochemical procedure, and a mosaic staining pattern was seen in 9 GISTs. The fixation periods in these cases were not significantly different from the remaining 12 tumors. Since c-kit protein immunoreactivity was observed in mast cells in the consecutive sections of the c-kit-negative GIST, it seems that the negative reaction was not false-negative. In this particular lesion, two possibilities should be considered: either the antigenicity of c-kit 
Table 4. Immunostaining for c-kit protein in 21 lesions of GIST

\begin{tabular}{|c|c|c|c|}
\hline $\begin{array}{r}\text { Immunostaining } \\
\text { Procedure }\end{array}$ & $\begin{array}{c}\text { Routine method of FHU Hospital } \\
\text { (Microwaving in CB7, Envision } \\
\text { method, and coloring reaction in } \\
\text { DAB20) }\end{array}$ & $\begin{array}{l}\text { Pressure cooking in EDTA, Simple } \\
\text { Stain method, and coloring reaction } \\
\text { in DakoCytomation's DAB }\end{array}$ & $\begin{array}{l}\text { Pressure cooking in } \mathrm{CB} 7, \text { Simple Stain } \\
\text { method, and coloring reaction in } \\
\text { DakoCytomation's DAB }\end{array}$ \\
\hline intensity & $\begin{array}{c}\text { number (median fixation period } \\
{[\text { days]/range of fixation period [days]) }}\end{array}$ & $\begin{array}{c}\text { number (median fixation period } \\
\text { [days]/range of fixation period [days]) }\end{array}$ & $\begin{array}{c}\text { number (median fixation period } \\
\text { [days]/range of fixation period [days]) }\end{array}$ \\
\hline 0 & $3(2 / 1 \sim 3)$ & $1(2 / 2)$ & $1(2 / 2)$ \\
\hline 1 & $2(1 / 1)$ & 0 & $2(1 / 1)$ \\
\hline 2 & $9(2 / 1 \sim 5)$ & $2(1 / 1)$ & $4(1.5 / 1 \sim 2)$ \\
\hline 3 & $7(2 / 1 \sim 4)$ & $18(2 / 1 \sim 5)$ & $14(2 / 1 \sim 5)$ \\
\hline total & $21(2 / 1 \sim 5)$ & $21(2 / 1 \sim 5)$ & $21(2 / 1 \sim 5)$ \\
\hline
\end{tabular}

Results are scored as "intensity".

Regarding the scoring method of intensity, see the legend to Table 1.

FHU: Fujita Health University

protein was deteriorated below the immunohistochemical detection threshold, or the tumor cells were truly negative for c-kit protein.

Gleevec is an orally administered competitive inhibitor of the tyrosine kinase domain of the c-kit protein, and has proven the efficiency in Philadelphia chromosome-positive chronic myeloid leukemia [4]. Malignant GISTs are commonly resistant to anti-cancer drugs and radiation [2]. Since Gleevec has been shown to decrease the proliferation of GISTs and to induce apoptosis, the therapeutic strategy of metastatic GISTs has been changed [2, 3, 19]. Side effects of Gleevec include myelosuppression [17], eruption [1, 14], and periorbital and brain edema $[5,6]$. It is thus important to make sure of the accuracy of the expression of c-kit protein in the case of GIST before deciding the administration of Gleevec. Although the procedure described above improved the immunostaining of c-kit protein localization, not all of the mast cells in sections were immunostained. This means that these methods are not yet ideal for detecting c-kit protein and still remains open to be improved technically. In addition, it still remains unknown whether or not the Gleevec therapy is really ineffective against immunohistochemically c-kit protein-negative GISTs. The nature of the c-kit proteinnegative GISTs definitely requires further investigation.

\section{References}

1. Brouard, M. C., Prins C., Mach-Pascual, S. and Saurat, J. H. (2001) Acute generalized exanthematous pustulosis associated with STI571 in a patient with chronic myeloid leukemia. Dermatology 203; 57-59.

2. Croom, K. F. and Perry, C. M. (2003) Imatinib mesylate: in the treatment of gastrointestinal stromal tumours. Drugs 63; 513522.

3. Demetri, G. D. (2003) Targeting c-kit mutations in solid tumors: scientific rationale and novel therapeutic options. Semin. Oncol. 28 (Suppl. 17); 19-26.

4. Druker, B. J., Sawyers, C. L., Kantarjian, H., Resta, D. J., Reese, S. F., Ford, J. M., Capdeville, R. and Talpaz, M. (2001) Activity of a specific inhibitor of the BCR-ABL tyrosine kinase in the blast crisis of chronic myeloid leukemia and acute lymphoblastic leukemia with the Philadelphia chromosome. N. Engl. J. Med. 344; 1038-1042.

5. Ebnoether, M., Stentoft, J., Ford, J., Buhl, L. and Gratwohl, A. (2002) Cerebral oedema as a possible complication of treatment with imatinib. Lancet 359; 1751-1752.

6. Esmaeli, B., Prieto, V. G., Butler, C. E., Kim, S. K., Ahmadi, M. A., Kantarjian, H. M. and Talpaz, M. (2002) Severe periorbital edema secondary to STI571 (Gleevec). Cancer 95; 881-887.

7. Kamoshida, S., Matsuoka, H., Matsuyama, A., Shimomura, R., Maruta, M. and Tsutsumi, Y. (2003) Reproducible and reliable immunohistochemical demonstration of thymidylate synthase in formalin-fixed, paraffin-embedded sections: application of antigen retrieval in EDTA solution. Acta Histochem. Cytochem. 36; $115-118$.

8. Kindblom, L. G., Remotti, H. E., Aldenborg, F. and MeisKindblom, J. M. (1998) Gastrointestinal pacemaker cell tumor (GIPACT): gastrointestinal stromal tumors show phenotypic characteristics of the interstitial cells of Cajal. Am. J. Pathol. 152; 1259-1269.

9. Krystal, G. W., Honsawek, S., Litz, J. and Buchdunger, E. (2000) The selective tyrosine kinase inhibitor STI571 inhibits small cell lung cancer growth. Clin. Cancer Res. 6; 3319-3326.

10. Miettinen, M., Sarlomo-Rikala, M. and Lasota, J. (1999) Gastrointestinal stromal tumors: recent advances in understanding of their biology. Hum. Pathol. 30; 1213-1220.

11. Natkunam, Y. and Rouse, R. V. (2000) Utility of paraffin section immunohistochemistry for C-KIT (CD117) in the differential diagnosis of systemic mast cell disease involving the bone marrow. Am. J. Surg. Pathol. 24; 81-91.

12. Rubin, B. P., Schuetze, S. M., Eary, J. F., Norwood, T. H., Mirza, S., Conrad, E. U. and Bruckner, J. D. (2002) Molecular targeting of platelet-derived growth factor B by imatinib mesylate in a patient with metastatic dermatofibrosarcoma protuberans. J. Clin. Oncol. 20; 3586-3591.

13. Sarlomo-Rikala, M., Kovatich, A. J., Barusevicius, A. and Miettinen, M. (1998) CD117: a sensitive marker for gastrointestinal stromal tumors that is more specific than CD34. Mod. Pathol. $11 ; 728-734$.

14. Schwarz, M., Kreuzer, K. A., Baskaynak, G., Dorken B. and le Coutre, P. (2002) Imatinib-induced acute generalized exanthematous pustulosis (AGEP) in two patients with chronic myeloid leukemia. Eur. J. Haematol. 69; 254-256.

15. Seidal, T. and Edvardsson, H. (1999) Expression of c-kit (CD117) and Ki67 provides information about the possible cell of origin and clinical course of gastrointestinal stromal tumours. Histopathology 34; 416-424. 
16. Shidham, V. B., Chivukula, M., Gupta, D., Rao, R. N. and Komorowski, R. (2002) Immunohistochemical comparison of gastrointestinal stromal tumor and solitary fibrous tumor. Arch. Pathol. Lab. Med. 126; 1189-1192.

17. Sumi, M., Tauchi, T., Shimamoto, T., Ishida, G., Nakajima, A., Ito, Y. and Ohyashiki, K. (2002) Chronic myeloid leukemia associated with sustained severe pancytopenia after imatinib mesylate therapy. Rinsho Ketsueki 43; 868-870 (in Japanese).

18. Tazawa, K., Tsukada, K., Makuuchi, H. and Tsutsumi, Y. (1999) An immunohistochemical and clinicopathological study of gastro- intestinal stromal tumors. Pathol. Int. 49; 786-798.

19. Tuveson, D. A., Willis, N. A., Jacks, T., Griffin, J. D., Singer, S., Fletcher, C. D., Fletcher, J. A. and Demetri, G. D. (2001) STI571 inactivation of the gastrointestinal stromal tumor c-KIT oncoprotein: biological and clinical implications. Oncogene 20; 50545058.

20. Wang, L., Vargas, H. and French, S. W. (2000) Cellular origin of gastrointestinal stromal tumors: a study of 27 cases. Arch. Pathol. Lab. Med. 124; 1471-1475. 